\title{
New Sources of Entrepreneurial Finance
}

\author{
Theo Lynn and Pierangelo Rosati
}

\begin{abstract}
Digital technologies are transforming entrepreneurial finance. Near-ubiquitous access to the Internet, platformisation, and advances in cloud computing, machine learning and artificial intelligence, and blockchain are changing the sources, basis, and quantum of funding in ways that were unimaginable at the turn of the century. This chapter outlines the changes to the market for entrepreneurial finance from the perspective of structure and participants. The key sources and characteristics of alternative sources of finance available to entrepreneurs, including start-ups, are presented. Two online alternative finance sources, crowdfunding and token offerings, are discussed in greater detail. These are illustrated with case studies. This chapter concludes with recommendations and a discussion of practical implications.
\end{abstract}

\section{Introduction}

Entrepreneurs are typically defined by their risk taking, innovation, and opportunity-seeking behaviour (Wennekers and Thurik 1999). Their contribution to economic growth is widely accepted. Entrepreneurship provides employment and income to a wide range of citizens and contributes to increased innovation, productivity, and competitiveness (OECD 2017; Wennekers and Thurik 1999). Despite this, the nascency of entrepreneurial ventures presents challenges for entrepreneurs in attracting the resources needed to survive and achieve and sustain economic success. This is particularly the case in sourcing finance. Limited credit histories,

T. Lynn $(\bowtie) \cdot$ P. Rosati

Irish Institute of Digital Business, DCU Business School, Dublin, Ireland

e-mail: theo.lynn@dcu.ie 
cash flow, under-collateralisation, lack of sophisticated financial statements, and higher default risks are just some of the factors that impede access to credit (Bhide 2003; Hall and Lerner 2010; OECD 2013). While entrepreneurs and SME owners report that credit conditions have improved in recent years, they also report that access to finance is a major concern (OECD 2019).

Entrepreneurs are exploiting new technologies to develop, market, and sell traditional and new products and services in new ways to global markets 24/7/365. At the same time, these technologies are changing how entrepreneurs access funding and from whom. As a result, a large number of new channels to investors have been introduced to the market mobilising new sources of capital. Entrepreneurs have never had so much choice with respect to sources of funding. The remainder of this chapter outlines the changing landscape of entrepreneurial finance and discusses two Internet-enabled sources of entrepreneurial finance in greater detail - crowdfunding and token offerings. These are illustrated with two case studies on Jolla Software and AspenCoin. The former raised over US\$1.8 million from over 13,000 contributors in 21 days using the IndieGoGo crowdfunding platform (Jolla 2014c), while the latter raised over US\$18 million through a security token offering (Carroll 2018b). The chapter concludes with a summary of the key takeaways for entrepreneurs.

\section{The New Alternatives for Entrepreneurial Finance}

Up until the turn of the century, the traditional sources of entrepreneurial finance were the so-called three "Fs"- friends, family, and fools - and then as a venture evolved, additional finance was sourced from business angels, venture capital firms, and capital markets (Bellavitis et al. 2017). Over the last twenty years, the market for entrepreneurial finance began to change in terms of both its structure and, relatedly, its participants (Harrison and Mason 2019). Table 1 summarises the structural changes and the implications of these changes for entrepreneurial finance.

Alongside the structural changes highlighted in Table 1, Harrison and Mason (2019) note that a large number of new actors have entered the market mobilising new sources of capital. To some extent, these new actors (presented in Table 2) mitigate the negative effects of structural changes by providing funding at formative stages (e.g. university or government venture capital), reactivating the three Fs, and providing a wider geographic reach for fundraising (e.g. crowdfunding), and democratising venture capital (e.g. token offerings-initial coin offerings (ICOs) and security token offerings (STOs)).

These new actors are re-conceptualising the funding cycle by introducing new peculiarities and dynamics (Brown et al. 2019; Martino et al. 2019). Rather than a relatively linear funding cycle, new sources of entrepreneurial finance can be used interchangeably and revisited many times (Bellavitis et al. 2017). Furthermore, they may not have financial goals or require equity at all. The peculiarities of these new 
Table 1 Major structural changes in the market for entrepreneurial finance in the last twenty years

\begin{tabular}{|c|c|c|}
\hline Structural change & Description & Implication \\
\hline $\begin{array}{l}\text { Demise of } \\
\text { "classic venture } \\
\text { capital" }\end{array}$ & $\begin{array}{l}\text { Withdrawal of institutional venture } \\
\text { capital from the start-up and } \\
\text { early-stage capital market due to the } \\
\text { economics of managing and } \\
\text { investing increasingly larger funds }\end{array}$ & $\begin{array}{l}\text { Smaller number of larger } \\
\text { transactions thus affecting business } \\
\text { development and economic growth }\end{array}$ \\
\hline $\begin{array}{l}\text { Closure of the } \\
\text { IPO market }\end{array}$ & $\begin{array}{l}\text { The IPO market is only available to } \\
\text { all intents and purposes to larger } \\
\text { companies }\end{array}$ & $\begin{array}{l}\text { Has resulted in "second equity gap" } \\
\text { and growing importance in } \\
\text { long-term angel investors }\end{array}$ \\
\hline $\begin{array}{l}\text { Emergence of } \\
\text { formally } \\
\text { organised angel } \\
\text { groups }\end{array}$ & $\begin{array}{l}\text { The development, often with } \\
\text { government support, of business } \\
\text { angel networks (BANs) which act as } \\
\text { matchmaking services for } \\
\text { entrepreneurs and investors }\end{array}$ & $\begin{array}{l}\text { Emergence of formal managed angel } \\
\text { syndicates, syndicate } \\
\text { managers/gatekeepers, formal and } \\
\text { informal alliances of angel investors } \\
\text { Demise of traditional funding } \\
\text { escalator and replacement with a } \\
\text { bundling model involving angel } \\
\text { groups co-investing with other funds }\end{array}$ \\
\hline $\begin{array}{l}\text { Identification of a } \\
\text { "scale-up" } \\
\text { problem }\end{array}$ & $\begin{array}{l}\text { The displacement of individual } \\
\text { business angels by BANs and the } \\
\text { requirement for larger long-term } \\
\text { investment commitments may result } \\
\text { in a "first equity gap" }\end{array}$ & $\begin{array}{l}\text { Downward management of } \\
\text { entrepreneurs' growth aspirations to } \\
\text { match the availability of capital }\end{array}$ \\
\hline $\begin{array}{l}\text { Changing } \\
\text { geography of } \\
\text { venture capital }\end{array}$ & $\begin{array}{l}\text { Venture capital investment tends to } \\
\text { be concentrated in a relatively small } \\
\text { number of the world's major cities }\end{array}$ & $\begin{array}{l}\text { Venture capital has an uneven } \\
\text { impact on urban and regional } \\
\text { economic development }\end{array}$ \\
\hline
\end{tabular}

Adapted from Harrison and Mason (2019)

sources of alternative funding reflect the heterogeneity of the stakeholders behind them. Their goals may be financial, non-financial, or a blend of both financial and non-financial in the case of government, university, and social venture capital funds. In other cases, funding may be provided by stakeholders who just like the idea or consider themselves fans (Block et al. 2018). Similarly, the benefits to firms include not only access to finance but infrastructure, customers, or legitimacy (Bellavitis et al. 2017).

\section{The Digital Alternatives: Online Alternative Finance}

Not all of the new sources of alternative finance are Internet-enabled. Online alternative finance involves soliciting funds from the public for a project or venture through an Internet-based intermediate platform. Like traditional financing, these may be debt or equity-based. The two most prominent categories of online alternative finance are crowdfunding (including peer-to-peer lending) and token offerings (including ICOs and STOs). The Global Crowdfunding Market was valued at 


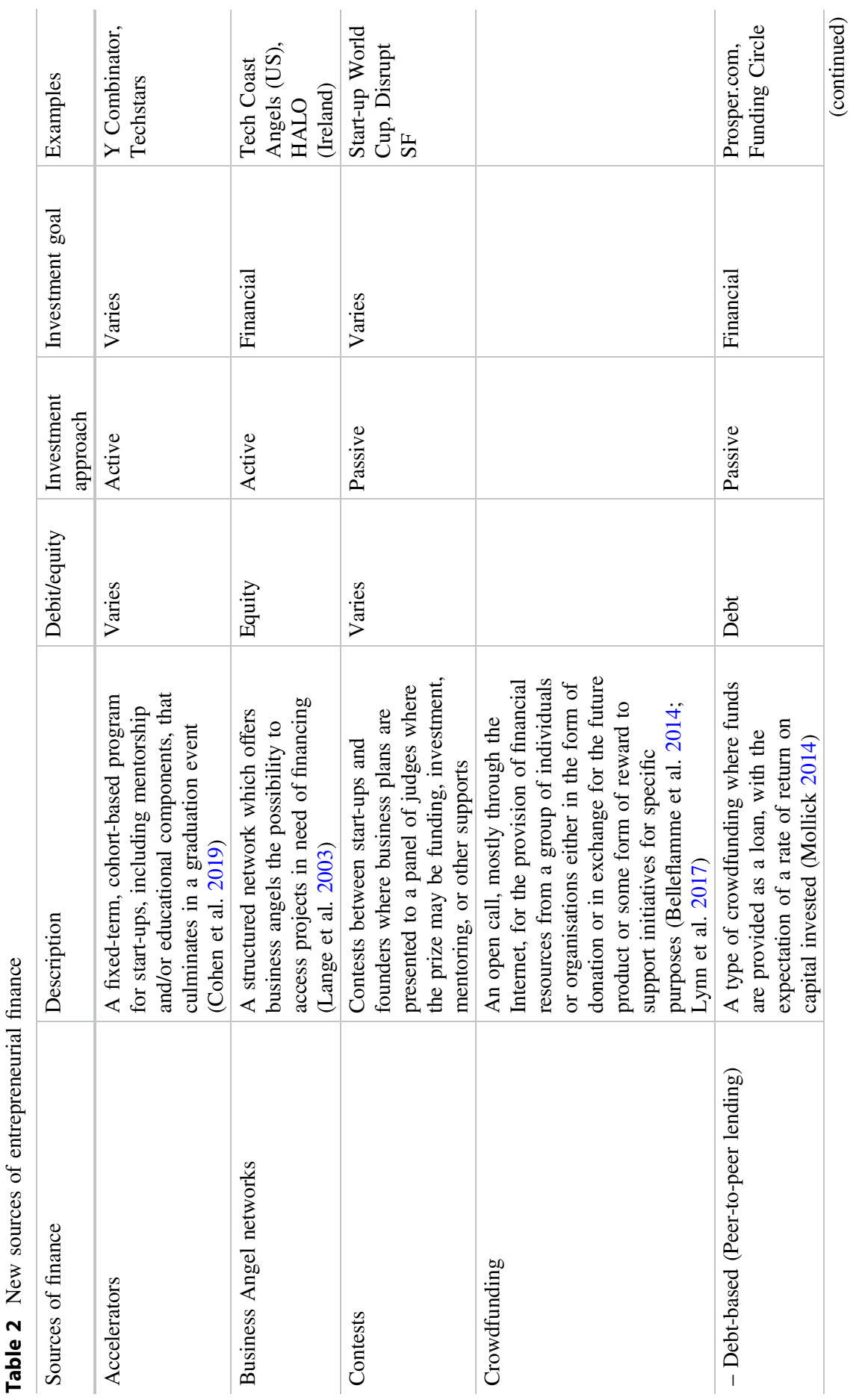




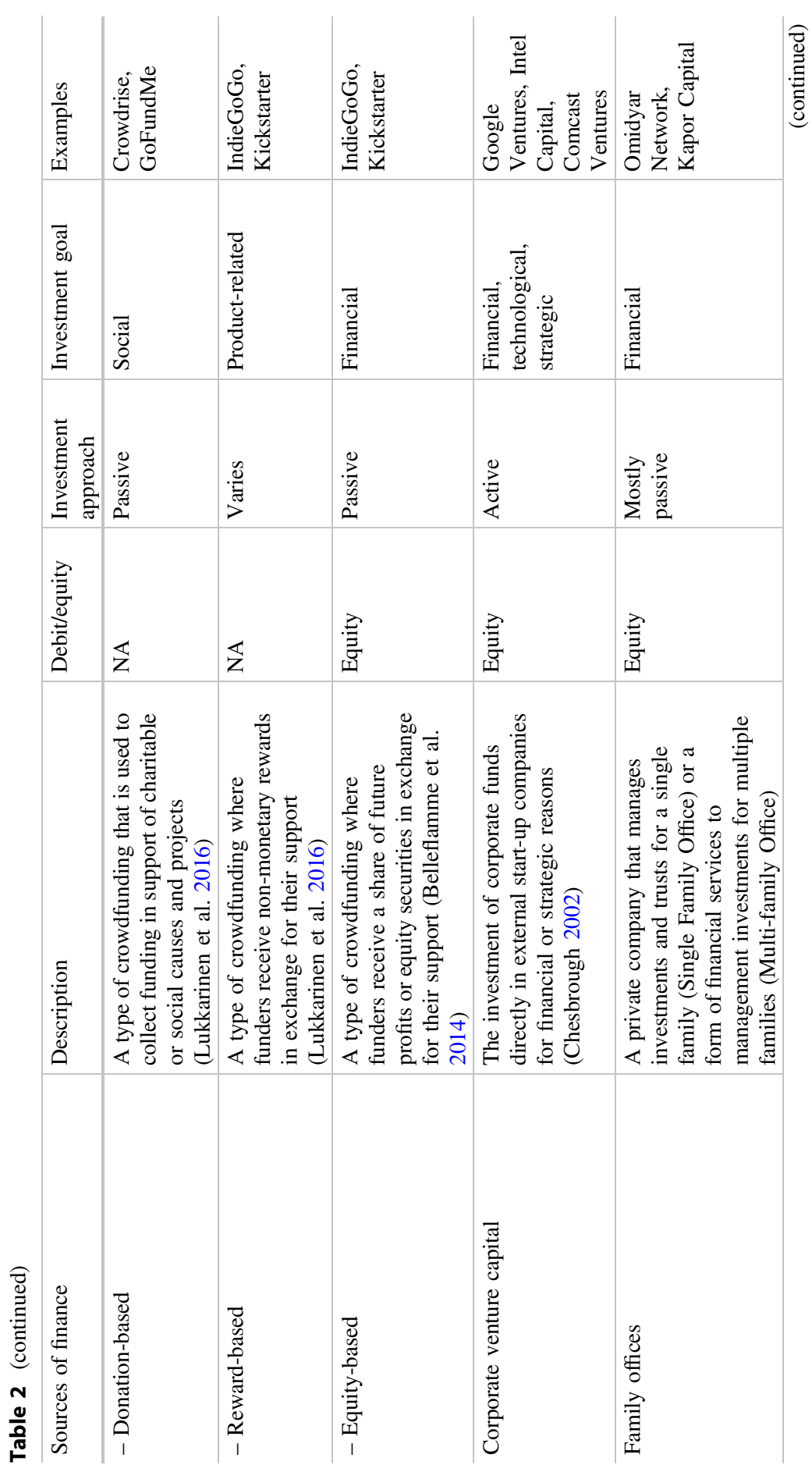




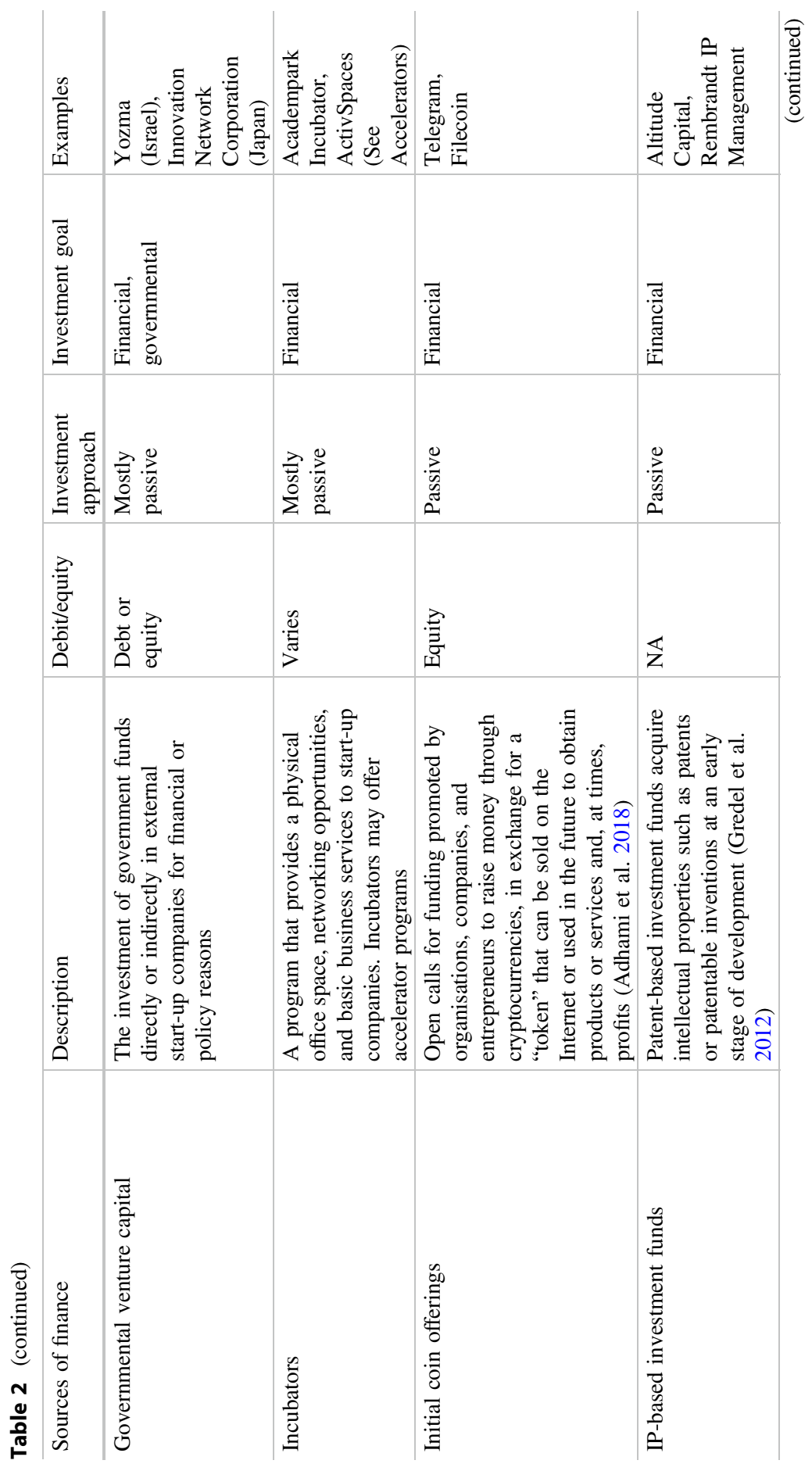




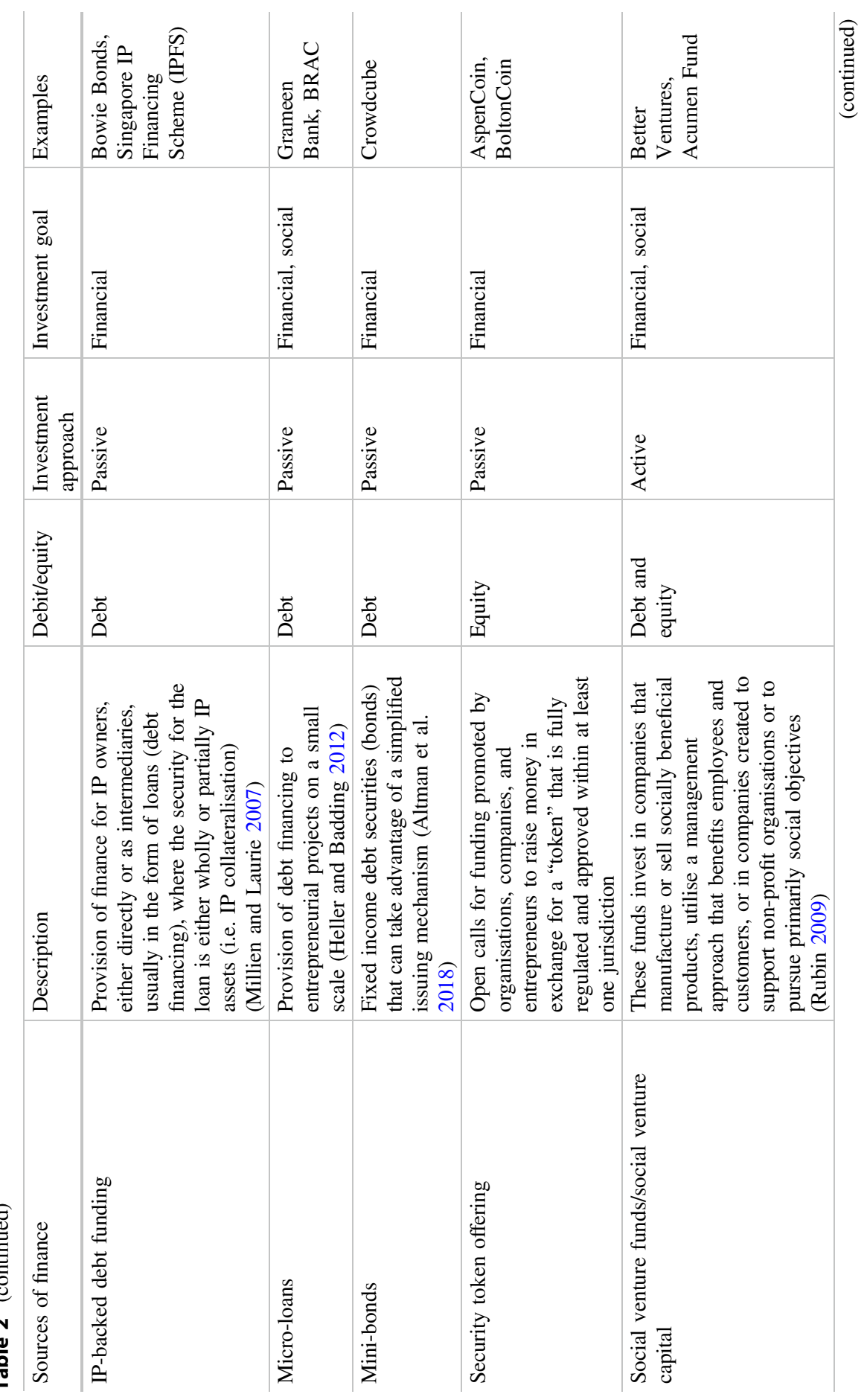




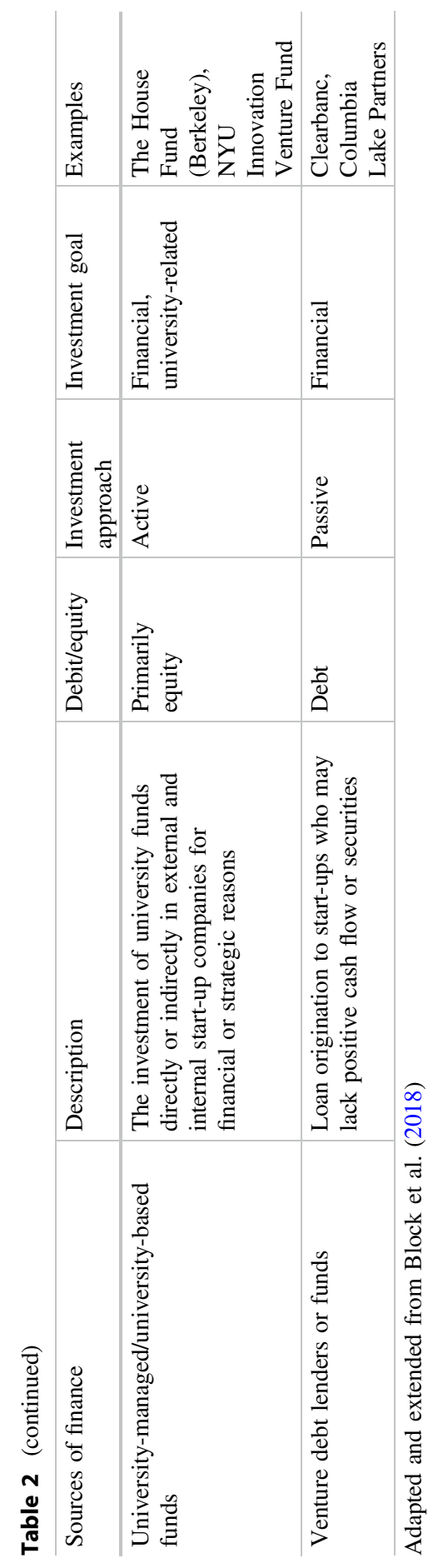


10.2 Billion US\$ in 2018 and is expected to reach 28.8 Billion US\$ with a CAGR of $16 \%$ by 2025 (Valuates Reports 2019). More recently, token offerings have gained traction providing more than $\$ 26$ billion in funding through more than 1700 thousand successful offerings (ICObench 2019a).

\subsection{Crowdfunding}

\subsubsection{Equity, Reward, and Donation Crowdfunding}

Crowdfunding enables entrepreneurs to attract external finance and develop their business idea by sourcing small amounts of money from a large number of individuals, typically non-professional, i.e. the "crowd" instead of relatively small group of professional investors (Ordanini et al. 2011; Belleflamme et al. 2014; Brown et al. 2019). Crowdfunding platforms exploit the power of the Internet and platformisation to create a two-sided market that links capital-seekers (crowdfunders) and capital givers (investors) generating revenues for themselves through a commission on funds (Haas et al. 2014; Zvilichovsky et al. 2013; Zaggl and Block 2019).

Figure 1 provides an overview of the typical process for a crowdfunding campaign. Promoters submit their project idea to a crowdfunding platform describing the idea, the amount of capital sought, the team, the reward promised, and the length of the campaign. Platforms typically allow promoters to upload interactive material. This may include images or video. A properly designed narrative is quite important for the success of crowdfunding campaigns and is considered an effective way of building legitimacy around new ventures and mobilising diverse and dispersed actors like crowdfunders (Frydrych et al. 2014; Manning and Bejarano 2017). Properly designed communication strategies, both pre and post-launch of a campaign are key elements for its success as they help creating awareness for the project (Gierczak et al. 2016). Furthermore, crowdfunding campaigns typically heavily rely on social media and online communication in order to reach a wide and dispersed audience and in particular potential investors unknown to the promoters (Agrawal et al. 2011; Lynn et al. 2017). Most of the funds tend to be collected during the first and the last weeks of campaigns, therefore, it is important to sustain communication and engagement efforts until the end of a campaign to maximise the amount of capital collected (Kuppuswamy and Bayus 2018).

Crowdfunding platforms do not borrow, pool, or lend money on their own account but enable investors to pledge funds, often on an or all-or-nothing or keep-it-all basis (Cumming et al. 2015; Haas et al. 2014) (see Table 3). The economic model for these platforms is typically a commission based on funds raised or donations received. As such, when a campaign ends, promoters receive the amount of capital raised net of the platform fee. A key differentiation of these platforms is that they cater for a wide range of projects including products, experience goods, social initiatives, and more recently, research projects. Since its emergence in 2010, crowdfunding has expanded in terms of the volume, variety, and value of 


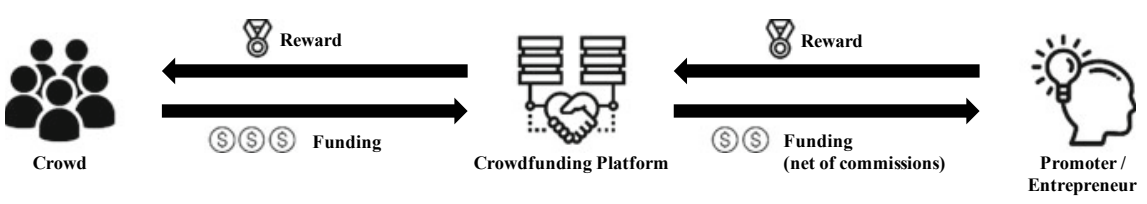

Fig. 1 Crowdfunding process

Table 3 All-or-nothing versus keep-it-all (Cumming et al. 2020)

\begin{tabular}{l|l}
\hline All-or-nothing & $\begin{array}{l}\text { Entrepreneurial firms set a capital raising goal below which the } \\
\text { entrepreneurial firm does not keep any of the pledged funds and the crowd } \\
\text { does not receive any reward }\end{array}$ \\
\hline Keep-it-all & $\begin{array}{l}\text { Entrepreneurial firms can keep the entire pledged amount regardless as to } \\
\text { whether or not the stated capital raising goal is reached }\end{array}$ \\
\hline
\end{tabular}

transactions to which it is applied (Agrawal et al. 2015). Massolution (2015) reported that crowdfunding investments worldwide grew to US $\$ 34.4$ billion in 2015 from over 1250 crowdfunding platforms.

Crowdfunding differs from traditional VC investments by the characteristics of investors, the investment model, and indeed the type of relationship the investors have with the investee. First, as mentioned earlier, unlike traditional investment, the overwhelming majority of crowdfunders are not professional but rather comprise friends, family, and those motivated by preferential access to products or feelings of connectedness to a community or a social cause (Gerber et al. 2012; Brown et al. 2019). Second, crowdfunding investment models are more varied than traditional investment and include crowdinvesting (lending and equity-based crowdfunding) and crowdsponsoring (donation, reward, and pre-purchase) (Griffin 2012). Third, the relationship between investors and investees in crowdfunding models differs from traditional investment (Ley and Weaven 2011). Due to the nature of crowdfunding, the ability to mitigate risk through deal screening, deal referrals, information sensitivity and due diligence before investment are limited. Similarly, ex-post risk mitigation through contractual rights, board representation, value adding capability, economic life, and exit options are also limited (Ley and Weaven 2011). In the case of donation and reward, and pre-purchase crowdfunding models, these may not even be relevant.

Conducting a crowdfunding campaign can be particularly beneficial for entrepreneurs as it provides them with access to capital but also generates a community effect around the project. Research suggests that many crowdfunders are motivated by early or preferential access to innovative products/services and feelings of connectedness to a community (Gerber and Hui 2013). As discussed earlier, crowdfunding also has the potential to eliminate geographical boundaries between entrepreneurs and investors therefore providing them access to a larger pool of resources and projects, respectively. This may result in more investment opportunities for capital givers and in more business and innovation, business and growth 
opportunities for entrepreneurs. However, cross-border opportunities have not been fully exploited by investors yet (Wardrop et al. 2015), and therefore, entrepreneurs should still focus on developing and leveraging their own local personal network. Critically, local investors tend to invest early, and this may represent an important signal to the other funders in the initial phase of campaign (Agrawal et al. 2011).

\subsubsection{Peer-to-Peer Lending}

Lending-based crowdfunding, typically referred to as peer-to-peer (P2P) lending, has attracted most of the crowdfunding investment so far. P2P lending platforms are typically quite targeted as they mostly focus on either personal or business lending with very few exceptions (e.g. LendingClub ${ }^{1}$ ). Table 4 provides an overview of the funding provided through $\mathrm{P} 2 \mathrm{P}$ lending platforms by region and segment.

Zopa was the first P2P lending platform to be launched back in 2005 (Cummins et al. 2019). Two other large US-based platforms, Prosper.com and LendingClub, followed in 2006 and 2007, respectively (Greiner and Wang 2009). However, the amount of capital channelled through P2P lending started growing significantly only post-2009, in the aftermath of the financial crisis. In fact, the combined effect of the crisis and the introduction of stricter banking regulations (e.g. Basel II) made access to capital extremely difficult for small enterprises and entrepreneurs. On the other hand, low interest rates made bonds and other traditional financial instruments unattractive for investors. In this context, P2P lending platforms started to prosper as they represented suitable alternatives to traditional channels for both businesses and investors.

$\mathrm{P} 2 \mathrm{P}$ lending is anything but new. Entrepreneurs have traditionally leveraged their personal network to raise capital (Berger and Udell 1998; Kotha and George 2012; Robb and Robinson 2014; Cummins et al. 2019). Small loans are often provided by family members or friends on the basis of personal relationships rather than formal due diligence. These informal transactions carry undeniable risks for both borrowers and lenders. Online P2P lending platforms have improved this process by providing online marketplaces that enable borrowers and lenders to transact directly with defined rules of engagement and by providing due diligence services that reduces the risk of default (Cummins et al. 2019). In exchange for this, platforms charge a fee, typically a small percentage of the funded amount, paid by borrowers.

A brief outline of the funding process for business loans on LendingClub is as follows. ${ }^{2}$ A potential borrower registers to the platform, provides verifiable contact and bank details together with the desired loan amount and duration. Then, the borrower provides additional background information about the business and its current financial status (e.g. last year's revenues and profits, ownership, and other existing financial commitments such as loans or leases). The approval process takes on average seven days, and the platform sets the interest rate based on its own risk

\footnotetext{
${ }^{1}$ https://www.lendingclub.com/.

${ }^{2}$ https://help.lendingclub.com/hc/en-us/articles/360001352047-Business-loan-application-walk through.
} 
Table 4 Size of P2P lending funding by region and segment

\begin{tabular}{|c|c|c|}
\hline Region & $\mathrm{P} 2 \mathrm{P}$ consumer lending & $\mathrm{P} 2 \mathrm{P}$ business lending \\
\hline \multicolumn{3}{|l|}{2015} \\
\hline The Americas & 18.00 & 2.60 \\
\hline Asia Pacific and China & 52.78 & 39.99 \\
\hline Europe & 0.40 & 0.23 \\
\hline Middle East and Africa & 0.01 & 0.02 \\
\hline \multicolumn{3}{|l|}{2016} \\
\hline The Americas & 21.10 & 1.30 \\
\hline Asia Pacific and China & 137.02 & 58.51 \\
\hline Europe & 0.73 & 0.37 \\
\hline Middle East and Africa & 0.03 & 0.03 \\
\hline \multicolumn{3}{|l|}{2017} \\
\hline The Americas & 14.90 & 1.50 \\
\hline Asia Pacific and China & 225.26 & 98.05 \\
\hline Europe & 1.39 & 0.47 \\
\hline Middle East and Africa & N/A & N/A \\
\hline
\end{tabular}

Notes All figures are reported in USD/billions

Sources Cambridge Centre for Alternative Finance (2017a, b, 2018a, b, c, d), Cummins et al. (2019)

assessment. If the borrower accepts the offered the proposed conditions, the funds are transferred to the provided bank account, and the borrower repays the loan to the platform on a monthly basis. The platform collects the monthly payments and transfers them to each backer on the basis of the amount funded. A key differentiator of online P2P loans when compared to traditional banking loans is that borrowers have the flexibility to make lump sum payments or repay their loans early at no extra cost. This flexibility, together with short approval times, is particularly valuable for businesses that face temporary liquidity needs.

The interest rates charged by $\mathrm{P} 2 \mathrm{P}$ lending platforms are on average higher than the ones offered by traditional financial institutions. This reflects the fact that P2P loans are typically riskier than the ones funded by banks (de Roure et al. 2016). P2P loans are mostly unsecured, and the access requirements for businesses are not as strict as the ones imposed by banks. For LendingClub, for example, a company would need to have been in business for a minimum of 12 months with at least $\$ 50,000$ in revenues. ${ }^{3}$ As such, $\mathrm{P} 2 \mathrm{P}$ lending platforms are complementary to traditional financial institutions as it allows riskier borrowers, which could not be served by banks, to obtain access to capital (de Roure et al. 2016). However, P2P lending platforms are also competing with traditional financial institutions for low risk borrowers (Tang 2019). In fact, investors (i.e. lenders) bear all the risk in P2P lending, and a key metric for them to evaluate platforms is default rate. As a result,

\footnotetext{
${ }^{3}$ https://www.lendingclub.com/business/?utm_source=LC\&utm_medium=link\&utm_campaign= pl_top_nav\&u=1.
} 
the rejection rate at the application stage is quite high for risky borrowers, and capital is more likely to flow towards borrowers who are already "bankable" (Tang 2019).

\subsubsection{Case Study: Jolla-The Power of the Crowd}

In February 2010, Intel and Nokia merged their efforts to develop a Linux-based mobile operating system (OS), MeeGo, and agreed to work together to drive a broad ecosystem of partners (Grabham 2010). For a short time, this partnership seemed to make progress, attracting companies like Novell, AMD and Aminocom to the MeeGo development effort. This all came to a shuddering stop exactly one year later when Nokia abandoned the partnership to switch to Windows Phone 7 (Reuters 2011). Intel soon followed and by October 2011 (Ricknas 2011), the MeeGo development effort had migrated to a new community effort named Mer (Mer Project 2011).

The switch to Windows Phone 7 was a major blow to Nokia. This strategy change contributed significant to nearly 24,000 job losses (Blandford 2012). To support those made unemployed, Nokia launched the Bridge programme. Under this programme, an ex-employee can potentially receive up to $€ 25,000$ in seed funding for a start-up company and up to four employees can come together for one start-up (Blandford 2012). One such group of former Nokia employees came together to form a new company, Jolla, to evolve the MeeGo/Mer OS. Jolla's plan was to license the new OS, Sailfish OS, to smartphone manufacturers, but this was not without challenges. Sami Pienimaki, cofounder of Jolla, told Engadget:

'We realised that we had to develop our own phone in order to bring life to the Sailfish operating system' (Summers 2018).

After suffering a number of setbacks, the Jolla phone launched in November 2013 to lukewarm reviews. Undeterred by the lacklustre reception, Jolla continued to market and sell its Sailfish-based smartphones. It also refocussed its efforts to demonstrate the capabilities of Sailfish OS in the emerging tablet market. A big question remained unanswered. How would it market and fund this new tablet effort?

On 19 November 2014, a year after launching its smartphone, the Jolla Tablet Indiegogo crowdfunding campaign was announced. Marc Dillon, the then CEO launched the campaign:

\footnotetext{
'Crowdsourcing has been the foundation of so many amazing, inspiring and independent products, and what it stands for taps directly into Jolla's ethos. We have a strong worldwide community supporting us, and we want to give people the opportunity to contribute early and take part in the Jolla Tablet campaign. By contributing you also have the opportunity to have your say in the actual development of the product' (Jolla 2014a).
}

As part of the Jolla Tablet campaign, the first thousand contributors were given the opportunity to get a Jolla Tablet for US\$189 and assuming the campaign hit its target of US\$380,000, product shipments would start in the second quarter of 2015. 
The campaign was made available in all EU countries, Norway, Switzerland, the USA, India, China, Hong Kong, and Russia. Jolla supported the campaign with PR, online advertising, and social media but also by seeking feedback on product features from the community.

By 27 November, Jolla had pledges of nearly US\$1.3 million, exceeding its original target by nearly 3X (Jolla 2014b). Riding the momentum, Dillon decided to use the feedback on product features to incentivise more investment. Jolla announced an extended phase of their crowdfunding campaign with the promise of new hardware and software features (3.5G HSDPA, extended memory card support, and split screen UI), if a new target of US $\$ 2.5$ million was reached, nearly $6.5 \mathrm{X}$ the original campaign target (Jolla 2014b). Dillon announced:

\footnotetext{
'We are really excited to announce these new stretch goals, which we've carefully identified and discussed together with our community. We asked what our backers want, and we hope we get to fulfil these promises. The highest stretch goal, adding the 3.5G HSDPA connectivity, has been in our hopes for a while already, and now we're looking forward to build further partnerships with cellular operators across the markets' (Jolla 2014b).
}

Would they succeed? By the time, the Jolla IndieGoGo campaign ended on 10 December, Jolla raised over US\$1.8 million from over 13,000 contributors in 21 days (Jolla 2014c). Including post-campaign contributions, Jolla raised over US $\$ 2.5$ million from 21,633 contributors (IndieGoGo 2019). The campaign's original target was reached in two hours, and US\$1 million in funding was raised in the first 24 hours. The campaign not only raised valuable funding but helped build a brand and international customer base in less than a month. Antti Saarnio, Chairman of the Board of Jolla commented:

\footnotetext{
'Involving fans and followers early through a crowdfunding campaign is a perfect way to launch a new product, and also to test the demand in advance. We are really pleased with the outcome, and are happy and thankful to see so many early contributors participating. Jolla has a strong worldwide community who believe in us and this campaign is one proof of that' (Jolla 2014c).
}

\subsection{Token Offerings}

\subsubsection{Initial Coin Offerings}

Initial token offerings, often referred to as initial coin offerings (ICOs), are, at first glance, similar to crowdfunding campaigns as they represent open calls for funding. However, they have critical differences in that they are completely disintermediated, typically are of orders of magnitude larger in terms of participants and value, and are established on blockchain-based smart contracts. Although token offerings represent a recent phenomenon, more than US\$27 billion has been raised through ICOs since 2013, with exponential growth over the last two years (PwC 2019). Figure 2 provides an overview of how ICOs work.

The unencumbered nature of ICOs has attracted the attention of policy makers worldwide; in some countries (e.g. China), ICOs have even been deemed illegal 


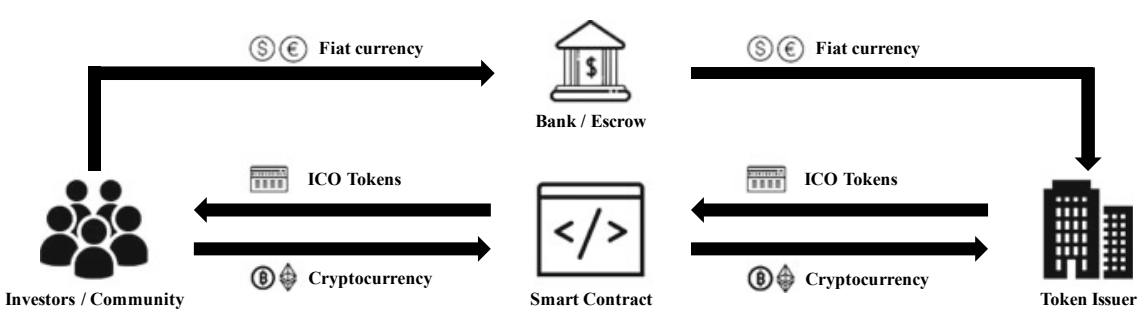

Fig. 2 ICO process (adapted from PwC 2019)

(Barsan 2017). As such, entrepreneurs aiming to launch an ICO should first verify the legal implications of conducting an ICO in the jurisdiction that they, and potential investors, are based in.

The token issuer, typically a start-up, defines the main characteristics of the tokens (e.g. the rights it will provide to token holders, number of tokens, protocol, etc.) and of the selling process (e.g. initial value, issuing platform, time period of token sale, type of investors, accepted methods of payment, etc.). There are three main types of tokens (Tasca 2019):

- Payment tokens which are essentially cryptocurrencies that are used as means of payment or value transfer;

- Utility tokens that allow token holders to access a specific digital application/service;

- Asset/debt tokens which represent for the investor assets such as a debt or equity.

From a project promoter's perspective, one of main benefits of token offerings is the opportunity to attract both capital and users, particularly with the issuance of utility tokens. This is particularly beneficial for platform promoters as reaching a critical mass of users is paramount for the success of the project. Unsurprisingly, platform-based businesses represent the majority of completed token offerings so far, followed by projects related to cryptocurrencies (ICObench 2019b). As this type of fundraising matures, the number of token offerings across other industries is expected to grow, particularly in the IT sector.

Once the token and the sale process have been designed, the entire project is then described in a "white paper". A white paper typically contains the technical details related to the token offering but also a detailed description of the project and the team. The white paper is a key element for the success of a token offering (Adhami et al. 2018), and its production typically involves considerable cost (Fisch 2019). The white paper then needs to be promoted to potential investors. In this phase, a properly built website, and a clear marketing and communication strategy can make the difference in terms of reaching potential target investors in the most effective way. This phase typically requires time and effort as awareness needs to be built around the proposed project. 
Once launched, the duration of the sale depends on how attractive the project is to investors and how effective the pre-sale communication is. Gnosis' ICO, for example, concluded in 10 minutes $^{4}$; others may last for weeks or months. Many do not reach the minimum threshold at all. If the token offering is successful, the next step is for the promoters to deliver on their promises. This includes delivering tokens to the buyers and getting the tokens listed on one or more exchanges. One of the advantages of token offerings compared to traditional VC investments or crowdfunding campaigns is that tokens can be traded in the secondary market (Benedetti and Kostovetsky 2018). Tokens' price fluctuates based on progress in product development and project's future prospects (Benedetti and Kostovetsky 2018). Despite all the hype around token offerings and the announcements of multi-million sales frequently reported in the media, the failure rate of token offerings is quite high. According to a recent report published by Satis Group LLC, only 15 percent of the ICOs launched so far managed to get to the listing stage, and approximately, 50 percent of them are deemed to be successful (Satis Group 2018).

\subsubsection{Security Token Offerings}

Although very attractive from a financial standpoint, token offerings face two main challenges. Firstly, ICOs suffer from legitimacy issues arising from $78 \%$ of past ICO initiatives being perceived or designated as scams (Satis Group 2018). ${ }^{5}$ Unsurprisingly, many investors still look at token offerings with suspicion. This also relates to the second challenge - ambiguous regulation. As mentioned previously, ICOs were, and still are, completely unregulated in many countries. As such, investor protection is very limited at best or non-existent at worst. Some regulators have recently provided clearer frameworks by making asset/debt tokens comparable to more standard securities like debt or equities. This has enabled the development of more legitimate, transparent, and regulated token offerings (also known as security token offerings-STOs). What distinguishes STOs from ICOs is that STO tokens pass what is called "The Howey Test"-there is (i) an investment of money, (ii) profits are expected, (iii) money investment is a common enterprise, and (iv) any profits come from the efforts of a third party (Henning 2018). As such, unlike ICOs, STOs are defined as securities and therefore face the same regulation as equity shares while retaining the advantages of cryptocurrencies over traditional private markets in terms of liquidity, price discovery, and market makers. STOs are particularly attractive for profit-driven established investors who are looking to acquire a stake in these innovative ventures. From a promoter perspective, the process of launching and conducting an STO is similar to the one for ICOs presented previously with two key differences mostly related to compliance (Lee et al. 2019). Firstly, token issuers need to pay more attention to compliance with local security law requirements and to fully understand the legal implications of the STO for both the issuing company and investors. Secondly, token issuers must provide potential

\footnotetext{
${ }^{4}$ https://cointelegraph.com/news/fastest-ever-ico-ethereum-based-gnosis-creates-300-mln-inminutes-raising-12-mln.

${ }^{5}$ https://medium.com/@ sherwin.dowlat/ico-quality-development-trading-e4fef28df04f.
} 
investors with a prospectus, a legal document which contains detailed information about the offering and the financial elements of your offering. The prospectus has to be approved by a financial regulator and is designed to protect investors from fraud.

\subsubsection{Case Study: Aspen Coin-The First Real Estate STO}

Aspen, Colorado is one of the most expensive towns in the USA. Founded as a mining town in the nineteenth century, the development of the Aspen area into a ski resort heralded unprecedented real estate investment into the area and a skyrocketing of property prices that has continued today. Reliable snow, a variety of ski terrains, historic neighbourhoods, year-round events, and celebrity cachet have resulted in a proliferation of second homes adding to the already superheated property market. In 2017, Aspen had the highest entry threshold for high-end properties across the USA (Block 2017).

The St. Regis Aspen Resort is a five-star luxury destination nestled at the base of Aspen Mountain managed by a subsidiary of Marriott International. It is owned by Aspen REIT, Inc. In November 2017, Aspen REIT announced its intention to be the first single-asset REIT to list on a national exchange by offering 1,675,000 shares at US\$20 per share on the NYSE American stock exchange (Aspen REIT 2017). At the time, Aspen REIT CEO Stephane De Baets said:

'We plan to bring to the market a first-of-its-kind real estate offering that provides individual investors with the opportunity to own shares in a highly attractive, trophy asset in the St. Regis Aspen Resort. Historically, the chance to own a portion of an individual property of this calibre and stature was only available to institutions. With our offering, we are changing this model while at the same time providing individual investors with liquidity optionality for a single-asset investment. Our value proposition is innovative and, we believe, highly compelling' (Aspen REIT 2017).

However, in March 2018, Aspen REIT withdrew its common stock from listing on the New York Stock Exchange. It had other plans. De Baets told the Aspen Times:

'...we believe many people secretly want to own a piece of the St. Regis Aspen hotel. Owning a digital token is the equivalent of owning a share, and is a digital security. We saw that doing an IPO was not scalable through the traditional route. Seeing where the blockchain market was heading, we saw the opportunity to be first-movers with our token offering for the St. Regis Aspen' (Carroll 2018a).

In August 2018, Templum Markets launched Aspen Digital, a tokenised asset offering (TAO), on Templum's trading platform. Aspen Digital is a digital Reg D 506c security offering open to accredited investors (Templum Markets 2018). Each token, called an Aspen Coin, represents, through indirect ownership, one share of common stock in the St. Regis Aspen Resort. Aspen Coins can be bought with US dollars, BitCoin or Ethereum. More important, all Aspen Coins are backed by the St. Regis Aspen Resort asset. De Baets clearly felt he had found a more efficient, cost-effective, and liquid means to raise funds: 
'Asset backed coins like the Aspen Coin not only offer a transformative way to invest in real estate, but also establish a new way to store wealth by utilizing collateralized and income generating digital assets...we believe that the real estate tokenization model has tremendous potential in that it brings liquidity and disintermediation to the world's largest asset class' (Templum Markets 2018).

Reg D 506c offerings differ from public offerings, such as the Aspen REIT IPO on the NYSE. For example, investors do not obtain voting rights, something that favours the promoter. While Reg D 506c are open to the public to some extent, they are technically private placements that are only open to non-US persons or "accredited investors" in the US for the first year. Accredited investors must meet income, network, or asset thresholds as well as know your customer (KYC) and anti-money laundering (AML) requirements. However, this only applies to US investors; overseas investors do not need to meet these requirements. Standard ICOs do not have the same thresholds or requirements. Notwithstanding this, the offering can be advertised widely with no dollar limit on offering size and much lower disclosure thresholds. These lower compliance requirements reduce a perceived burdensome overhead while addressing legitimation issues associated with ICOs. Furthermore, participation is not limited to "those in the know". Indeed, the Aspen Coin offering was relatively self-service. Interested parties registered on the Templum Markets platform and provided documentation to verify accredited investor status and meet the KYC/AML requirements. Once verified, investors could participate in the offering; the minimum investment was US\$10,000.

In addition to Templum's existing network of investors, the Aspen Coin offering was marketed to the nine million users of IndieGoGo, a first for the global crowdfunding platform. IndieGoGo co-founder Slava Rubin explained their motivation:

\footnotetext{
'We have always strived to foster innovation and provide our users access to some of the most novel and interesting products and ideas from around the world. With the blockchain revolution fully underway, we at Indiegogo are excited about the world-changing impact and potential of security tokens. Our goal is to [perform diligence for] each company and provide an access point to our growing network of millions of customers. And it's a privilege to work with the St. Regis Aspen Resort' (Wolfson 2018).
}

So was the Aspen Coin offering successful? On 9 October 2018, Aspen Digital announced $18.9 \%$ of the St. Regis Aspen Resort ownership through US $\$ 18$ million in tokens (Carroll 2018b).

\section{Conclusion}

Entrepreneurs and SMEs have an unprecedented range of funding sources to draw from. Digital technologies are providing new opportunities for value creation, value capture, and value delivery for not only entrepreneurs but also investors. Online alternative finance is both disintermediating and democratising entrepreneurial finance transforming the access, relationship, and dynamics between supply and 
demand and providing valuable alternatives for entrepreneurial ventures at different stages of development. While P2P lending is better suited for both traditional and established businesses with existing revenue streams but need of small, short-term loans to meet monthly loan repayments or for small investments (Fenwick et al. 2018), other forms of crowdfunding are better suited for early-stage riskier ventures in need for capital to fund their prototype or initial growth (Harrison 2013). Similar to crowdfunding, token offerings are particularly attractive for early-stage ventures although mostly suited to platform-based businesses and have been adopted by start-ups aiming to avoid the complicated and costly auditing, and regulatory burden of traditional funding models (Tasca 2019), they are also typically larger in scale than traditional crowdfunding.

While new Internet-enabled funding mechanisms, such as crowdfunding and token offerings, have the potential to transform entrepreneurial finance and play a significant role in creating a level global playing field for access to funding, it remains concentrated in a small number of markets and raises a number of public policy issues, not least investor protection. The trajectory of these financing innovations is only going one way. Whether they will replace or complement the existing funding cycle remains to be seen.

\section{References}

Adhami, S., Giudici, G., \& Martinazzi, S. (2018). Why do businesses go crypto? An empirical analysis of initial coin offerings. Journal of Economics and Business, 100, 64-75.

Agrawal, A., Catalini, C., \& Goldfarb, A. (2015). Crowdfunding: Geography, social networks, and the timing of investment decisions. Journal of Economics \& Management Strategy, 24(2), 253-274.

Agrawal, A. K., Catalini, C., \& Goldfarb, A. (2011). The geography of crowdfunding (No. w16820). National Bureau of Economic Research.

Altman, E. I., Esentato, M., \& Sabato, G. (2018). Assessing the credit worthiness of Italian SMEs and mini-bond issuers. Global Finance Journal, 43, 100450.

Aspen REIT. (2017, November 14). Aspen REIT, Inc. Files for Initial Public Offering; Targets NYSE American Listing. Press Release. https:/www.businesswirechina.com/en/news/ 36375.html. Accessed 7 July 2019.

Barsan, I. M. (2017). Legal challenges of initial coin offerings (ICO). Revue Trimestrielle de Droit Financier $(R T D F)$, 3, 54-65.

Bellavitis, C., Filatotchev, I., Kamuriwo, D. S., \& Vanacker, T. (2017). Entrepreneurial finance: New frontiers of research and practice: Venture Capital 19 (1-2), 1-16. https://doi.org/10. 1080/13691066.2016.1259733.

Belleflamme, P., Lambert, T., \& Schwienbacher, A. (2014). Crowdfunding: Tapping the right crowd. Journal of Business Venturing, 29(5), 585-609.

Benedetti, H., \& Kostovetsky, L. (2018). Digital tulips? Returns to investors in initial coin offerings (May 20, 2018).

Berger, A. N., \& Udell, G. F. (1998). The economics of small business finance: The roles of private equity and debt markets in the financial growth cycle. Journal of Banking \& Finance, 22(6), 613-673.

Bhide, A. (2003). The origin and evolution of new business. New York: Oxford University Press. 
Blandford, R. (2012, July 18). Nokia's Bridge program aims to ease pain of job losses. All About Symbian. http://www.allaboutsymbian.com/flow/item/15297_Nokias_Bridge_program_aims_ to_php. Accessed 8 July 2019.

Block, F. (2017, July 27). Aspen, Colorado, has the highest entry price in the U.S. for luxury homes. Mansion Global. https://www.mansionglobal.com/articles/aspen-colorado-has-thehighest-entry-price-in-the-u-s-for-luxury-homes-69765. Accessed 7 July 2019.

Block, J. H., Colombo, M. G., Cumming, D. J., \& Vismara, S. (2018). New players in entrepreneurial finance and why they are there. Small Business Economics, 50(2), 239-250.

Brown, R., Mawson, S., \& Rowe, A. (2019). Start-ups, entrepreneurial networks and equity crowdfunding: A processual perspective. Industrial Marketing Management, 80, 115-125.

Cambridge Centre for Alternative Finance. (2017a). Hitting stride-The Americas Alternative Finance Industry Report.

Cambridge Centre for Alternative Finance. (2017b, September). Cultivating growth-The 2nd Asia Pacific Region Alternative Finance Industry Report.

Cambridge Centre for Alternative Finance. (2018a). Expanding horizons-The 3rd European Alternative Finance Industry Report.

Cambridge Centre for Alternative Finance. (2018b, June). The 2nd Annual Middle East and Africa Alternative Finance Industry Report.

Cambridge Centre for Alternative Finance. (2018c, November). The 3rd Asia Pacific Region Alternative Finance Industry Report.

Cambridge Centre for Alternative Finance. (2018d, December). The 3rd Americas Alternative Finance Industry Report.

Carroll, R. (2018a, September 2). Business monday: Digital tokens, blockchain technology and the St. Regis Aspen. Aspen Times. https://www.aspentimes.com/news/local/business-mondaydigital-tokens-blockchain-technology-and-the-st-regis-aspen/. Accessed 7 July 2019.

Carroll, R. (2018b, November, 9). In \$18 million deal, nearly one-fifth of St. Regis Aspen sells through digital tokens. Aspen Times. https://www.aspentimes.com/trending/in-18-million-dealnearly-one-fifth-of-st-regis-aspen-sells-through-digital-tokens/. Accessed 7 July 2019.

Chesbrough, H. W. (2002). Making sense of corporate venture capital. Harvard Business Review, 80(3), 90-99.

Cohen, S., Fehder, D. C., Hochberg, Y. V., \& Murray, F. (2019). The design of startup accelerators. Research Policy, 48(7), 1781-1797.

Cumming, D. J., Leboeuf, G., \& Schwienbacher, A. (2015). Crowdfunding models: Keep-it-all vs. all-or-nothing. Financial Management, 44, 1-30.

Cummins, M., Lynn, T., Mac an Bhaird, C., \& Rosati, P. (2019). Addressing information asymmetries in online peer-to-peer lending. In Disrupting finance (pp. 15-31). Cham: Palgrave Pivot.

Cumming, D. J., Leboeuf, G., \& Schwienbacher, A. (2020). Crowdfunding models: Keep-it-all vs. all-or-nothing. Financial Management, 49(2), 331-360.

de Roure, C., Pelizzon, L., \& Tasca, P. (2016). How does P2P lending fit into the consumer credit market? Bundesbank Discussion Paper No. 30/2016. Available at SSRN: https://ssrn.com/ abstract=2848043.

Fenwick, M., McCahery, J. A., \& Vermeulen, E. P. (2018). Fintech and the financing of SMEs and entrepreneurs: From crowdfunding to marketplace lending. In The economics of crowdfunding (pp. 103-129). Cham: Palgrave Macmillan.

Fisch, C. (2019). Initial coin offerings (ICOs) to finance new ventures. Journal of Business Venturing, 34(1), 1-22.

Frydrych, D., Bock, A. J., Kinder, T., \& Koeck, B. (2014). Exploring entrepreneurial legitimacy in reward-based crowdfunding. Venture Capital, 16(3), 247-269.

Gerber, E. M., \& Hui, J. (2013). Crowdfunding: Motivations and deterrents for participation. ACM Transactions On Computer-Human Interaction (TOCHI), 20(6), 34. 
Gerber, E. M., Hui, J. S., \& Kuo, P. Y. (2012, February). Crowdfunding: Why people are motivated to post and fund projects on crowdfunding platforms. In Proceedings of the international workshop on design, influence, and social technologies: techniques, impacts and ethics (Vol. 2, No. 11, p. 10). Northwestern University Evanston, IL.

Gierczak, M. M., Bretschneider, U., Haas, P., Blohm, I., \& Leimeister, J. M. (2016). Crowdfunding: Outlining the new era of fundraising. In Crowdfunding in Europe (pp. 7-23). Cham: Springer.

Grabham, D. (2010, February 10). Intel and Nokia merge Moblin and Maemo to form MeeGo. Techradar.com. https://www.techradar.com/news/phone-and-communications/mobile-phones/ intel-and-nokia-merge-moblin-and-maemo-to-form-meego-670302. Accessed 8 July 2019.

Gredel, D., Kramer, M., \& Bend, B. (2012). Patent-based investment funds as innovation intermediaries for SMEs: In-depth analysis of reciprocal interactions, motives and fallacies. Technovation, 32(9-10), 536-549.

Greiner, M. E., \& Wang, H. (2009). The role of social capital in people-to-people lending marketplaces. In ICIS 2009 proceedings, 29.

Griffin, Z. J. (2012). Crowdfunding: Fleecing the American masses. Case Western Reserve Journal of Law, Technology \& the Internet, 4, 375.

Haas, P., Blohm, I. \& Leimeister, J.M. (2014). An empirical taxonomy of crowdfunding intermediaries. In Proceedings of Thirty Fifth International Conference on Information Systems, Auckland 2014. AIS.

Hall, B. H., \& Lerner, J. (2010). The financing of R\&D and innovation. In Handbook of the economics of innovation (Vol. 1. pp. 609-639). Amsterdam: Elsevier.

Harrison, R. (2013). Crowdfunding and the revitalisation of the early stage risk capital market: Catalyst or chimera? Venture Capital, 15(4), 283-287

Harrison, R. T., \& Mason, C. M. (2019). Venture Capital 20 years on: Reflections on the evolution of a field. Venture Capital, 21(1), 1-34.

Heller, L. R., \& Badding, K. D. (2012). For compassion or money? The factors influencing the funding of micro loans. The Journal of Socio-Economics, 41(6), 831-835.

Henning, J. (2018). The Howey test: Are crypto-assets investment contracts. University of Miami Business Law Review, 27, 51.

ICObench. (2019a). ICO market monthly analysis, October 2019. Available at: https://icobench. com/reports/ICObench_ICO_Market_Analysis_October_2019.pdf. Accessed 3 Dec 2019.

ICObench. (2019b). Stats and facts. Available at: https://icobench.com/stats. Accessed 30 July 2019.

Indiegogo. (2019). Jolla Tablet - world's first crowdsourced tablet. Available at: https://www. indiegogo.com/projects/jolla-tablet-world-s-first-crowdsourced-tablet\#/.

Jolla. (2014a, November 19). Introducing Jolla Tablet, the world's first crowdsourced tablet project. Press Release. https://jolla.com/wp-content/uploads/2017/02/41_JOLLATABLET_ IGG_PRESSRELEASE_NOV2014_FINAL.pdf?x54860. Accessed 8 July 2019.

Jolla. (2014b, November 27). Jolla Tablet project has more than tripled its goal by raising nearly $\$ 1.3 \mathrm{M}$; now introducing 3.5G cellular data campaign goal and more. https://jolla.com/ wp-content/uploads/2017/02/44_JOLLATABLET_UPDATE_PRESSRELEASE_NOV2014_ FINAL.pdf?x54860. Accessed 8 July 2019.

Jolla. (2014c, December 11). Jolla successfully ends the Jolla tablet crowdfunding campaign and closes financing round B. https://jolla.com/wp-content/uploads/2017/02/46_JOLLATABLET_ STRATEGY_PRESS_RELEASE_DEC2014_FINAL.pdf?x54860. Accessed 8 July 2019.

Kotha, R., \& George, G. (2012). Friends, family, or fools: Entrepreneur experience and its implications for equity distribution and resource mobilization. Journal of Business Venturing, $27(5), 525-543$.

Kuppuswamy, V., \& Bayus, B. L. (2018). Crowdfunding creative ideas: The dynamics of project backers. In The economics of crowdfunding (pp. 151-182). Cham: Palgrave Macmillan.

Lange, J., Leleux, B., \& Surlemont, B. (2003). Angel networks for the 21st century: An examination of practices of leading networks in Europe and the US. The Journal of Private Equity, 6(2), 18-28. 
Lee, J., Li, T., \& Shin, D. (2019). The wisdom of crowds in FinTech: Evidence from initial coin offerings. Available at SSRN 3195877.

Ley, A., \& Weaven, S. (2011). Exploring agency dynamics of crowdfunding in start-up capital financing. Academy of Entrepreneurship Journal, 17(1), 85.

Lukkarinen, A., Teich, J. E., Wallenius, H., \& Wallenius, J. (2016). Success drivers of online equity crowdfunding campaigns. Decision Support Systems, 87, 26-38.

Lynn, T., Rosati, P., Nair, B., \& Mac an Bhaird, C. (2017). Harness the crowd: An exploration of the crowdfunding community on Twitter. In ISBE Annual Meeting 2017.

Manning, S., \& Bejarano, T. A. (2017). Convincing the crowd: Entrepreneurial storytelling in crowdfunding campaigns. Strategic Organization, 15(2), 194-219.

Martino, P., Bellavitis, C., \& DaSilva, C. M. (2019). Blockchain and initial coin offerings (ICOs): A new way of crowdfunding. Available at SSRN 3414238.

Massolution. (2015). Crowdfunding Industry Report.

Mer Project. (2011). Mer is back. http://mer-project.blogspot.com/2011/10/. Accessed 8 July 2019.

Millien, R., \& Laurie, R. (2007, October). A summary of established \& emerging IP business models. In The Sedona Conference, Phoenix, AZ.

Mollick, E. (2014). The dynamics of crowdfunding: An exploratory study. Journal of Business Venturing, 29(1), 1-16.

OECD. (2013). SME and entrepreneurship financing: The role of credit guarantee schemes and mutual guarantee societies in supporting finance for small and medium-sized enterprises. Paris: OECD Publishing. https://www.oecd-ilibrary.org/economics/sme-and-entrepreneurshipfinancing_35b8fece-en. Accessed 27 July 2019.

OECD. (2017). Enhancing the contributions of SMEs in a global and digitalized economy. Paris: OECD Publishing. https://www.oecd.org/mcm/documents/C-MIN-2017-8-EN.pdf. Accessed 8 July 2019.

OECD. (2019). Financing SMEs and entrepreneurs 2019: An OECD scoreboard. Paris: OECD. https://www.oecd.org/cfe/smes/financing-smes-and-entrepreneurs-23065265.htm. Accessed 8 July 2019.

Ordanini, A., Miceli, L., Pizzetti, M., \& Parasuraman, A. (2011). Crowd-funding: Transforming customers into investors through innovative service platforms. Journal of Service Management, 22(4), 443-470.

PWC. (2019). 4th ICO/STO report-A strategic perspective. Available at: https://cryptovalley. swiss/wp-content/uploads/ch-20190308-strategyand-ico-sto-report-q1-2019.pdf. Accessed 30 July 2019.

Reuters. (2011, February 11). Nokia drops first MeeGo phone before launch-sources. https:// www.reuters.com/article/nokia-meego/nokia-drops-first-meego-phone-before-launch-sourcesidUSLDE7180X420110209. Accessed 8 July 2019.

Ricknas, M. (2011, September 28). Intel drops MeeGo mobile OS, backs Tizen against Android. ComputerWorld. https://www.computerworld.com/article/2511522/intel-drops-meego-mobileos-backs-tizen-against-android.html. Accessed 8 July 2019.

Robb, A. M., \& Robinson, D. T. (2014). The capital structure decisions of new firms. Review of Financial Studies, 27(1), 153-179.

Rubin, J. S. (2009). Developmental venture capital: Conceptualizing the field. Venture Capital, $11(4), 335-360$.

Satis Group LLC. (2018). Cryptoasset market coverage initiation: Network creation. Available at: https://research.bloomberg.com/pub/res/d28giW28tf6G7T_Wr77aU0gDgFQ. Accessed 2 Aug 2019.

Summers, N. (2018, March 1). The Finns who refuse to give up on Sailfish OS. https://www. engadget.com/2018/03/01/jolla-sailfish-os-team-interview-mwc/. Accessed 8 July 2019.

Tang, H. (2019). Peer-to-peer lenders versus banks: Substitutes or complements? The Review of Financial Studies, 32(5), 1900-1938.

Tasca, P. (2019). Token-based business models. In T. Lynn, J. Mooney, M. Cummins, \& P. Rosati (Eds.), Disrupting finance (pp. 135-148). Cham: Palgrave Pivot. 
Templum Markets. (2018, August 8). Templum Markets launches digital security offering of St. Regis Aspen Resort. Press Release. https://www.businesswire.com/news/home/20180808005549/en/ Templum-Markets-Launches-Digital-Security-Offering-St. Accessed 7 July 2019.

Valuates Reports. (2019). The global crowdfunding market was valued at 10.2 billion US\$ in 2018 and is expected to reach 28.8 billion US\$ with a CAGR of $16 \%$ by 2025 . Valuates Reports. Available at: https://www.prnewswire.com/in/news-releases/the-global-crowdfunding-marketwas-valued-at-10-2-billion-us-in-2018-and-is-expected-to-reach-28-8-billion-us-with-a-cagr-of16-by-2025-valuates-reports-888819175.html. Accessed 4 Dec 2019.

Wardrop, R., Zhang, B., Rau, R., \& Gray, M. (2015). Moving mainstream. The European Alternative Finance Benchmarking Report, 15-16.

Wennekers, S., \& Thurik, R. (1999). Linking entrepreneurship and economic growth. Small Business Economics, 13(1), 27-56.

Wolfson, R. (2018, August, 23). Crowdfunding giant Indiegogo expands into crypto-security tokens with tokenized shares of stock. Forbes. https://www.forbes.com/sites/rachelwolfson/ 2018/08/23/crowdfunding-giant-expands-into-security-tokens-with-tokenized-shares-of-stockin-st-regis-resort/. Accessed 7 July 2019.

Zaggl, M. A., \& Block, J. (2019). Do small funding amounts lead to reverse herding? A field experiment in reward-based crowdfunding. Journal of Business Venturing Insights, 12, e00139.

Zvilichovsky, D., Inbar, Y. \& Barzilay, O. (2013). Playing both sides of the market: Success and reciprocity on crowdfunding platforms. In Proceedings of the Thirty Fourth International Conference on Information Systems, Milan 2013. AIS.

Open Access This chapter is licensed under the terms of the Creative Commons Attribution 4.0 International License (http://creativecommons.org/licenses/by/4.0/), which permits use, sharing, adaptation, distribution and reproduction in any medium or format, as long as you give appropriate credit to the original author(s) and the source, provide a link to the Creative Commons license and indicate if changes were made.

The images or other third party material in this chapter are included in the chapter's Creative Commons license, unless indicated otherwise in a credit line to the material. If material is not included in the chapter's Creative Commons license and your intended use is not permitted by statutory regulation or exceeds the permitted use, you will need to obtain permission directly from the copyright holder.

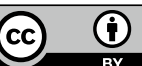

